\title{
Palynology of species of Anthemideae, Eupatorieae, Inuleae, Mutiseae and Senecianeae tribes occurring in the region of Campos Gerais, Paraná State, Brazil
}

\author{
Carin Stanski', Rosemeri Segecin Moro², Melissa Koch Fernandes de Souza Nogueira ${ }^{3}$, \\ Yoshiko Saito Kuniyoshi ${ }^{4}$ \& Cynthia Fernandes Pinto da Luz ${ }^{5}$
}

\begin{abstract}
' Universidade Federal do Paraná, Avenida Lothário Meissner, 632, Jardim Botânico, Curitiba, Paraná, Brasil. carin.stansk@gmail.com 2 Universidade Estadual de Ponta Grossa, Departamento de Biologia Geral, Laboratório de Palinologia. Av. General Carlos Cavalcanti, 4748, CEP 84030-900,Ponta Grossa, PR, Brasil. moro.vepg@gmail.com

${ }^{3}$ Universidade Estadual de Ponta Grossa, Departamento de Biologia Geral, Laboratório de Palinologia. Av. General Carlos Cavalcanti, 4748, CEP 84030-900, Ponta Grossa, PR, Brasil. melissaknog@yahoo.com.br

${ }^{4}$ Universidade Federal do Paraná, Avenida Lothário Meissner, 632, Jardim Botânico, Curitiba, PR, Brasil. yoshiko@ufpr.br 5Instituto de Botânica de São Paulo, Núcleo de Pesquisa em Palinologia, Av. Miguel Estéfano, 3687, Água Funda, CEP 04301-012, São Paulo, SP, Brasil. cynthialuz@gmail.com
\end{abstract}

Received on 02.111.2016

Accepted on 04.XII.2018

DOI 10.21826/2446-8231201873312

ABSTRACT - We analyzed the pollen morphology of ten species belonging to nine genera of the Asteraceae family, with one species belonging to the Anthemideae tribe (Matricaria chamomilla L.), three belonging to the Eupatorieae [Chromolaena laevigata (Lam.) R. M. King \& H. Rob., Mikania micrantha Kunth and Vittetia orbiculata (DC.) R.M.King \& H.Rob.], two to the Inuleae (Achillea millefolium L. and Gnaphalium purpureum L.), two to the Mutiseae [Chaptalia integerrima (Vell.) Burkart and Chaptalia graminifolia (Dusén ex Malme) Cabrera], and two species belonging to the Senecioneae tribe [Emilia sonchifolia (L.) DC. and Senecio brasiliensis (Spreng.) Less.]. We used acetolysis to carry out the palynological analysis and pollen grains were studied under light and scanning electron microscopy. The tribes were considered eurypalynous, whose morphological detail allowed the subdivision of species in four groups related to pollen types Anthemis, Eupatorium, Centaurea and Senecio, previously defined in the literature.

Keywords: eurypalynous, palynotaxonomy, pollen grains

RESUMO - Palinologia de espécies das Tribos Anthemideae, Eupatorieae, Inuleae, Mutiseae e Senecianeae ocorrentes na região dos Campos Gerais, Paraná, Brasil. Foi analizada a morfologia polínica de dez espécies pertencentes a nove gêneros da família Asteraceae, sendo uma espécie pertencente à tribo Anthemideae [Matricaria chamomilla L.], três à Eupatorieae [Chromolaena laevigata (Lam.) R. M. King \& H. Rob., Mikania micranta Kunth e Vittetia orbiculata (DC.) R. M. King \& H. Rob.], duas à Inuleae [Achillea millefolium L. e Gnaphalium purpureum L.], duas à Mutiseae [Chaptalia integerrima (Vell.) Burkart e Chaptalia graminifolia (Dusén ex Malme) Cabrera], e duas espécies à tribo Senecioneae [Emilia sonchifolia (L.) DC. e Senecio brasiliensis (Spreng.) Less.]. Para a análise dos grãos de pólen realizou-se acetólise e estes foram observados em microscopia óptica e eletrônica de varredura. As tribos foram consideradas euripolínicas e o detalhamento morfopolínico permitiu a subdivisão das espécies em cinco grupos relacionados aos tipos polínicos Anthemis, Eupatorium, Centaurea e Senecio previamente definidos na literatura.

Palavras-chave: euripolínico, grãos de pólen, palinotaxonomia

\section{INTRODUCTION}

The Asteraceae has the largest number of taxa within Angiosperms, with about 23,000 species and 17 tribes. According to APG III (2009), the Asteraceae family is inserted in the Asterids clade of the Asterales order. In Brazil, there are 14 tribes and according to Mondin (2006), the Eupatorieae tribe covers most generic richness in Brazil with 85 genera. The Mutiseae tribe is in fourth place having 25 genera, the Senecioneae with seven genera, and the Anthemideae with only two genera.

The pollen grains of Asteraceae (Anthemideae, Eupatorieae, Inuleae, Mutiseae and Senecioneae) here were previously described by Cancelli (2008) and Cancelli et al. $(2005,2010)$ from specimens collected in the state of Rio Grande do Sul (including Chaptalia integerrima, Chromolaena laevigata (Eupatorium laevigatum), Mikania micrantha and Senecio brasiliensis). Chaptalia integerrima was also described by Pastana (1988) in a palynological study with 14 Brazilian species from the Mutiseae tribe, belonging to the National Museum Herbarium - RJ. The pollen grains of Mikania micrantha were also studied by Mendonça \& Gonçalves-Esteves (2000) in a study with species from the Eupatorieae occurring at Restinga de Carapebus, Carapebus - RJ. While studying medicinal plants from Ilha Grande in Rio de Janeiro, Galvão et al. 
(2009) described Matricaria chamomilla (Chamomilla recutita) pollen grains and their medicinal use. Meo \& Khan (2003), described pollen characteristics of some Achillea genus specimens in Pakistan, including Achillea millefolium. The pollen grains of Emilia sonchifolia were studied for structural morphology by Adedeji (2005) in a study developed in Nigeria with three species of the genus Emilia Cass.

In the first stage of the studies on pollen grains in the Campos Gerais region, the pollen morphology of ten species belonging to five genera and two tribes were analyzed (Stanski et al. 2013). This study focuses on the morphological characterization of pollen grains from species of the Asteraceae family within Anthemideae, Eupatorieae, Inuleae, Mutiseae and Senecioneae, occurring in the Campos Gerais region, Paraná, Brazil, contributing to palynological and paleoecological studies.

\section{MATERIALS AND METHODS}

The plant material used was obtained from flower buds removed from vouchers held at the herbarium at the Universidade Estadual de Ponta Grossa (HUPG), Paraná, Brazil. The species most representative of the Campos Gerais region were selected based on a list carried out by the HUPG herbarium and floristic survey of the region. For each species, the pollen of at least three flower buds was removed to standardize size variations of pollen grains (Salgado-Labouriau 1973).

Pollen grains were prepared according to the acetolysis method by Erdtman (1952), with modifications proposed by Melhem et al. (2003), for light microscopy observation. Measurements were made using the Olympus OSM micrometric drum coupled to the microscope eyepiece of an Olympus BX 50 microscope. The measurements of the polar and equatorial axes were made in an equatorial view in 25 pollen grains distributed in five slides for each species, aiming at the uniformity of the sample. The measurements of the apertures, thickness and dimensions of the morphological structures of the exine were performed randomly in 10 pollen grains and only the arithmetic means was calculated (Salgado-Labouriau 1973). Measurements of the polar and equatorial axes in the equatorial view were performed using a magnification of $1.200 \mathrm{X}$ and for the apertures, thickness and exine ornamentation, a magnification of $2000 \mathrm{X}$ was used. Subsequently, a statistical analysis was performed by calculating the arithmetic mean (x), standard deviation (sx), sample standard deviation (s), coefficient of variation (CV), with the significance interval at $95 \%$ and variation range.

To better characterize the pollen grain ornamentation, the width of the base and height of the spines were obtained, yielding indices that define classes which varied between species as in Coutinho \& Dinis (2007) for Asteraceae and Barth et al. (2005) for Cucurbitaceae.
An index equal to 1.01 was obtained for spines with a base width proportional to the height; indices below 0.89 to 0.98 slightly wider at the base than tall and below 0.64 spines much wider at the base than long, i.e., short spines. It was also possible to characterize the apex/tip appearance (straight or curved), as well as the columellae and cavities at the spine base, mainly under scanning electron microscopy (SEM), differing in number and height among the species.

The terminology adopted was proposed by Punt et al. (2007) and Punt \& Hoen (2009), considering the size, shape, number of apertures and the sexine ornamentation patterns. The species and their respective authors were consulted on the botanical site (Tropicos ${ }^{\circledR}$ ) of the Missouri Botanical Garden.

The acetolysed pollen grains prepared for light microscopy were digitally photographed with the photomicroscope Leica DM 2500 coupled to a video camera and a computer using the LAS EZ 1.6.0 software. For the analysis under scanning electron microscopy, nonacetolysed pollen grains were spread under the surface of double-sided carbon tape wrapped in aluminum brackets ("stubs"), properly numbered. The samples were transferred to a vacuum pump and sputter coated with a thin layer of gold palladium (ca. 150 angstroms thick). The samples were then analyzed using a Shimadzu SSX-550 model belonging to the Scanning Electron Microscopy Laboratory at the Materials Engineering Department at the Universidade Estadual de Ponta Grossa.

The pollen characteristics shared among the species of each tribe are stated below. The general palynological characteristics that each tribe shares are presented under the tribe name. They were omitted from specific descriptions to avoid information being duplicated.

\section{RESULTS}

In the following section, we will describe the pollen morphology descriptions of ten species belonging to nine genera of the Asteraceae, occurring in the Campos Gerais, Paraná State, Brazil. One species belongs to the Anthemideae (Matricaria chamomilla L.), three species belong to the Eupatorieae [Chromolaena laevigata (Lam.) R. M. King \& H. Rob., Vittetia orbiculata (DC.) R. M. King $\&$ H. Rob. and Mikania micrantha Kunth], two species belong to the Inuleae tribe (Achillea millefolium L. and Gnaphalium purpureum L.), two species belong to the Mutiseae tribe [Chaptalia integerrima (Vell.) Burkart and Chaptalia graminifolia (Dusén ex Malme) Cabrera] and two species belong to the Senecioneae tribe [Emilia sonchifolia (L.) DC. and Senecio brasiliensis (Spreng.) Less.] occurring in Campos Gerais, Paraná State, Brazil.

The general morphological characterization and measurements of pollen grains of the studied species are shown in Tables 1-3. 
Table 1. General morphological characterization of pollen grains of the Asteraceae family in the Anthemideae, Eupatorieae, Inuleae, Mutiseae, and Senecioneae tribes occurring in Campos Gerais, Paraná state, Brazil.

\begin{tabular}{lccc}
\hline Species & Pollen size & Aperture & \multicolumn{1}{c}{ Colpus } \\
\hline Achillea millefolium & medium & 3-colporate & long size and narrow \\
Chaptalia graminifolia & medium & 3-colporate & long size and narrow \\
Chaptalia integerrima & medium & lalongate & lalongate \\
Chromolaena laevigata & small & long size and narrow \\
Emilia sonchifolia & medium & 3-colporate & long size and narrow \\
Gnaphalium purpureum & small & 3-colporate & long size and narrow \\
Matricaria chamomilla & small & 3-colporate & long size and narrow \\
Mikania micrantha & small & 3-colporate & long size and narrow \\
Senecio brasiliensis & small & 3-colporate & long size and narrow \\
Vittetia orbiculata & & 3-colporate & lang size and narrow \\
\hline
\end{tabular}

Table 2. Measurements $(\mu \mathrm{m})$ in equatorial view of the diameters $(\mathrm{n}=25)$ and arithmetic means of measurements of apertures $(\mathrm{n}=10)$ of polen grains of the species of Asteraceae from the tribes Anthemideae, Eupatorieae, Inuleae, Mutiseae and Senecioneae occurring in Campos Gerais, Paraná state, Brazil. $\mathrm{P}=$ Polar Diameter, $\mathrm{E}=$ equatorial diameter, $x=$ arithmetic mean, $s=$ sample standard deviation, $s x=$ mean standard deviation, $\mathrm{CI}=$ confidence interval $95 \%, \mathrm{~L}=$ length, $\mathrm{W}=$ width.

\begin{tabular}{|c|c|c|c|c|c|c|c|c|c|c|c|c|}
\hline \multirow[t]{2}{*}{ Species } & \multicolumn{3}{|c|}{$\mathrm{P}$} & \multicolumn{3}{|c|}{$\mathrm{E}$} & \multirow[t]{2}{*}{$\mathrm{P} / \mathrm{E}$} & \multirow[t]{2}{*}{ Shape } & \multicolumn{2}{|c|}{ Colpus } & \multicolumn{2}{|c|}{ Endoaperture } \\
\hline & $s$ & $x \pm s x$ & CI 95\% & $s$ & $x \pm s x$ & CI 95\% & & & $\mathrm{L}$ & W & $\mathrm{L}$ & W \\
\hline $\begin{array}{l}\text { Achillea } \\
\text { millefolium }\end{array}$ & 1.8 & $19.3 \pm 0.4$ & $18.6-20.0$ & 2.4 & $24.3 \pm 0.5$ & $23.3-25.3$ & 0.79 & suboblate & 16.98 & 2.95 & 8.96 & 1.86 \\
\hline $\begin{array}{l}\text { Chaptalia } \\
\text { graminifolia }\end{array}$ & 1.9 & $32.4 \pm 0.4$ & $31.6-33.2$ & 1.6 & $30.2 \pm 0.3$ & $29.6-31.0$ & 1.06 & $\begin{array}{c}\text { oblate- } \\
\text { spheroidal }\end{array}$ & 28.6 & 2.87 & 11.06 & 2.28 \\
\hline $\begin{array}{l}\text { Chaptalia } \\
\text { integerrima }\end{array}$ & 2.7 & $42.8 \pm 0.5$ & $41.7-43.9$ & 2.1 & $31.2 \pm 0.4$ & $30.0-32.1$ & 1.37 & prolate & 32.68 & 3.40 & 13.4 & 3.42 \\
\hline $\begin{array}{l}\text { Chromolaena } \\
\text { laevigata }\end{array}$ & 2.4 & $19.2 \pm 0.2$ & $18.7-19.7$ & 1.5 & $17.5 \pm 0.1$ & $17.1-17.8$ & 1.06 & $\begin{array}{l}\text { prolate- } \\
\text { spheroidal }\end{array}$ & 13.96 & 3.39 & 6.41 & 1.65 \\
\hline $\begin{array}{l}\text { Emilia } \\
\text { sonchifolia }\end{array}$ & 1.8 & $26.9 \pm 0.4$ & $26.1-27.6$ & 2.1 & $25.9 \pm 0.4$ & $25.1-26.1$ & 1.03 & $\begin{array}{l}\text { prolate- } \\
\text { spheroidal }\end{array}$ & 19.64 & 4.15 & 5.46 & 5.44 \\
\hline $\begin{array}{l}\text { Gnaphalium } \\
\text { purpureum }\end{array}$ & 0.6 & $16.4 \pm 0.1$ & $16.2-16.7$ & 0.9 & $16.0 \pm 0.2$ & $15.6-16.4$ & 1.02 & $\begin{array}{l}\text { prolate- } \\
\text { spheroidal }\end{array}$ & 13.96 & 3.39 & 6.41 & 1.65 \\
\hline $\begin{array}{l}\text { Matricaria } \\
\text { chamomilla }\end{array}$ & 2.2 & $16.6 \pm 0.4$ & $15.6-17.5$ & 1.7 & $16.6 \pm 0.3$ & $15.9-17.3$ & 1.00 & $\begin{array}{l}\text { prolate- } \\
\text { spheroidal }\end{array}$ & 12.00 & 2.52 & 10.57 & 3.47 \\
\hline $\begin{array}{l}\text { Mikania } \\
\text { micrantha }\end{array}$ & 1.0 & $15.6 \pm 0.2$ & $15.1-16.0$ & 1.0 & $15.2 \pm 0.3$ & $14.6-15.7$ & 1.02 & $\begin{array}{l}\text { prolate- } \\
\text { spheroidal }\end{array}$ & 13.92 & 1.91 & 5.30 & 1.07 \\
\hline $\begin{array}{l}\text { Senecio } \\
\text { brasiliensis }\end{array}$ & 1.5 & $26.9 \pm 0.3$ & $26.2-27.5$ & 1.3 & $26.6 \pm 0.3$ & $26.0-27.1$ & 1.01 & $\begin{array}{l}\text { prolate- } \\
\text { spheroidal }\end{array}$ & 21.12 & 4.89 & 11.60 & 3.17 \\
\hline $\begin{array}{l}\text { Vittetia } \\
\text { orbiculata }\end{array}$ & 3.2 & $17.9 \pm 0.6$ & $16.6-19.2$ & 1.9 & $18.4 \pm 0.4$ & $17.6-19.2$ & 0.97 & $\begin{array}{c}\text { oblate- } \\
\text { spheroidal }\end{array}$ & 12.56 & 2.69 & 5.95 & 1.80 \\
\hline
\end{tabular}

Table 3. Arithmetic mean of measurements $(\mu \mathrm{m})$ of pollen grain exine layer thickness of species of Asteraceae family in the tribes Anthemideae, Eupatorieae, Inuleae, Mutiseae and Senecioneae, occurring in Campos Gerais, Paraná state, Brazil. $(n=10) . N=$ nexine, CA = caveae, $\mathrm{S} 1=$ sexine 1 (columellar layer), S2 = sexine 2 (internal tectum), Cs = number of infrategillate columellae at the base of spines, Hs = length of spine, Ws $=$ width of spine basis, Hs/Ws = spine index, Fs = form of spine apex/tip ( $\mathrm{s}=$ straight spine apex and sc $=$ straight and curved spine apex $)$.

\begin{tabular}{|c|c|c|c|c|c|c|c|c|c|}
\hline Species & $\mathrm{N}$ & $\mathrm{CA}$ & $\mathrm{S} 1$ & $\mathrm{~S} 2$ & $\mathrm{Cs}$ & Hs & Ws & $\mathrm{Hs} / \mathrm{Ws}$ & Fs \\
\hline Achillea millefolium & 0.67 & 0.60 & 1.53 & 0.98 & 3 to 4 & 3.80 & 6.14 & 0.61 & $\mathrm{sc}$ \\
\hline Chaptalia graminifolia & 1.99 & ---- & 1.06 & 0.76 & ---- & ---- & ---- & ---- & --- \\
\hline Chaptalia integerrima & 1.77 & --- & 1.19 & 1.23 & --- & ---- & --- & ---- & --- \\
\hline Chromolaena laevigata & 0.83 & 1.48 & 1.04 & 0.84 & 4 to 5 & 2.93 & 3.23 & 0.90 & $\mathrm{~S}$ \\
\hline Emilia sonchifolia & 1.09 & Measured with Sex1 & 0.96 & 0.96 & 3 to 4 & 3.82 & 3.89 & 0.98 & $\mathrm{~S}$ \\
\hline Gnaphalium purpureum & 1.02 & 0.56 & 0.58 & 0.54 & 3 & 1.91 & 3.01 & 0.63 & $\mathrm{sc}$ \\
\hline Matricaria chamomilla & 1.02 & Measured with Sex1 & 2.52 & 0.72 & 4 to 5 & 3.30 & 5.67 & 0.58 & $\mathrm{~s}$ \\
\hline Mikania micrantha & 1.16 & 0.63 & 0.75 & 0.71 & 4 to 5 & 2.98 & 2.95 & 1.01 & $\mathrm{sc}$ \\
\hline Senecio brasiliensis & 0.85 & Measured with Sex1 & 0.83 & 0.78 & 3 to 4 & 3.46 & 5.36 & 0.64 & $\mathrm{sc}$ \\
\hline Vittetia orbiculata & 0.64 & 0.50 & 0.70 & 0.74 & 3 & 2.53 & 2.83 & 0.89 & $\mathrm{sc}$ \\
\hline
\end{tabular}


Anthemideae Cass.

(Figs. 1-3)

Matricaria L.

Matricaria chamomilla $\mathrm{L}$.

(Figs. 1-3)

Pollen grains of small size, isopolar, radial symmetry, amb subtriangular (Fig. 1), prolate-spheroidal, echinate. Aperture with longiaperturate colpi and narrow, acute ends, no central constriction. Endoaperture lalongate, without central constriction (Fig. 2). Exine with two distinct layers (sexine and nexine) with indistinct cavea. Simplicolumellate exine with sexine1 (columellae), sexine 2 (tectum) and sexine 3 (spines). The structure of the spines is of columellar and tegillum type, meaning they have a perforation at the base. Short spines (with about 4 columellae), much wider at the base than high (index 0.58), and with straight acute apex (Fig. 3), dome shaped (swollen at the base), spinular columellae are longer than the inter-spinular columellae. Sexine 3 times thicker than the nexine. Around 16 spines in polar view.

Note: Herbaceous plant, annual. Exotic, widely cultivated in almost all over the world, including in the southern states and southeastern Brazil (Lorenzi \& Matos 2002, Nakajima et al. 2015).

Eupatorieae Cass.

(Figs. 4-12)

Pollen grains of small size; isopolar; radial symmetry; amb subcircular or circular; oblate spheroidal or prolate oblate spheroidal; 3-colporate; echinate. Aperture longiaperturate and narrow, with acute ends, no central constriction (Fig. 8). Endoaperture circular or lalongate, with acute ends, without central constriction (Fig. 8).

Exine with two distinct layers (sexine and nexine) with indistinct cavea. Simplicolumellate exine with sexine 1 (columellae), sexine 2 (tectum), and sexine 3 (spines). The structure of the spines is of columellar and tegillum type, meaning they have a perforation at the base. Spines columellate, slightly larger at the base (base of spines swollen) then long or slightly longer than wide at the base, with acute and straight spine apex (Fig. 12); columellae infrategillate wider at the base of the spines and shorter between the spines. Sexine are twice as thick as the nexine.

\section{Chromolaena DC.}

Chromolaena laevigata (Lam.) R. M. King \& H. Rob. (Figs. 4-6)

Pollen prolate-spheroidal, amb circular. Aperture longiaperturate and narrow, endoaperture circular. Exine well-delimited cavea, spines longer (with about 4 columellae) than wide at the base (indix 0.90), and with straight acute apex. Arround 15 spines in polar view. Sexine 2 times thicker than nexine.

Note: Shrubby plant, perennial. Native, found throughout Brazil (Lorenzi 2000, Oliveira 2015).

\section{Mikania Willd. \\ Mikania micrantha Kunth}

(Figs. 10-12)

Pollen grains prolate-spheroidal, amb subcircular. Aperture longiaperturate and narrow, with acute ends. Endoaperture lalongate, without central constriction (Fig. 11).

Exine with well-delimited cavea. Spines longer (with around 4 columellae) than wide at the base (index 1.01), with an acute straight apex. Around 14 spines in polar view. Sexine 2 times thicker than nexine.

Note: Climber plant, perennial. Native, found throughout Brazil (Cabrera \& Klein 1989, Ritter et al. 2015).

Vittetia R. M. King \& H. Rob.

Vittetia orbiculata (DC.) R. M. King \& H. Rob.

(Figs. 7-9)

Pollen grains oblate-spheroidal, amb subcircular. Aperture longiaperturate and narrow, with acute ends. Endoaperture lalongate without central constriction (Fig. 8). Exine with well-delimited cavea. Spines with about 4 to 5 columellae, slightly larger at the base then long (index 0.89 ), and with straight acute apex. Around 14 spines in polar view. Sexine 2 times thicker than nexine.

Note: Sub-shrubby plant, perennial. Native, found in the southern states of Brazil (Cabrera \& Klein 1989, Ferreira 2015).

Inuleae Cass.

(Figs.13-18)

Pollen grains of small to medium size; isopolar; radial symmetry; amb subtriangular or subcircular (Fig. 16); suboblate or prolate-spheroidal; 3-colporate; echinate. Apertures longiaperturate colpi and narrow, with indistinct ends no central constriction (Fig. 17). Endoaperture lalongate, with narrowed ends, with or without central constriction (Fig. 17). Exine with two distinct layers (sexine and nexine) with cavea (well-delimited) and united only at the colpi. Simplicolumellate exine with sexine 1 (columellae), sexine 2 (tectum), and sexine 3 (spines, sculpture elements). The structure of the spines is of columellar and tegillum type, meaning they have a perforation at the base. The spinular columellae are longer than the inter-spinular columellae. Spines are slightly longer than wide at the base or as long as wide at the base, conical or curved (Fig. 13) (swollen at the base) and usually with acute and straight spine apex. Sexine 3 times thicker than the nexine. 

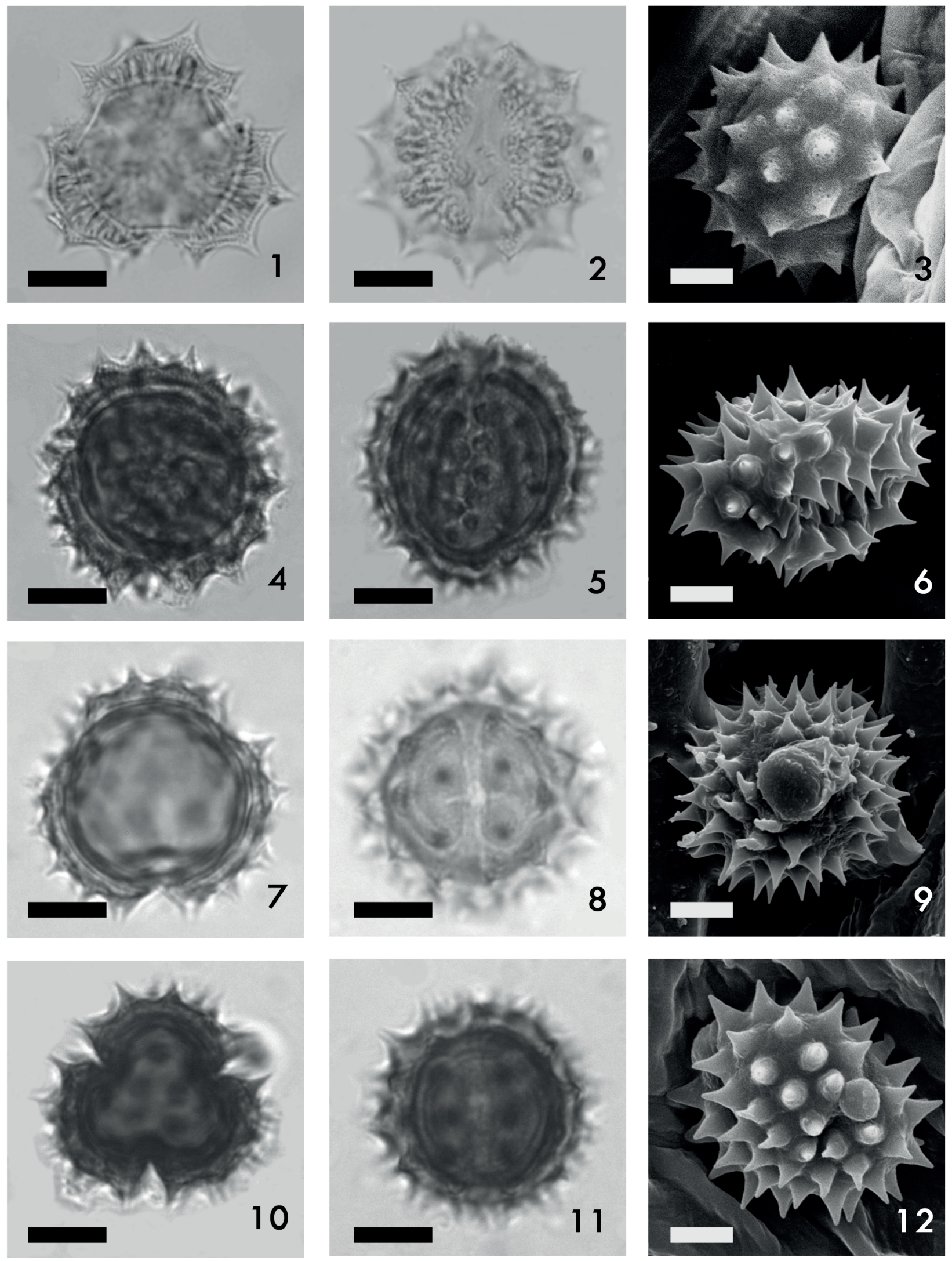

Figs. 1-12. Pollen grains of Asteraceae, tribes Anthemideae and Eupatorieae. 1-3. Matricaria chamomilla.1. Polar view (MO); 2. Equatorial view (MO); 3. General aspect (MEV). 4-6. Chromolaena laevigata. 4. Polar view (MO); 5. Equatorial view (MO); 6. General aspect (MEV). 7-9. Vittetia orbiculata. 7. Polar view (MO); 8. Equatorial view (MO); 9. General aspect (MEV). 10-12. Mikania micrantha. 10. Polar view (MO); 11. Equatorial view (MO); 12. General aspect (MEV). Bars: Figs. 1, 2, 4, 5, 7, 8, 10, $11=10 \mu \mathrm{m}$; Figs. 3, 6, 9, $12=5 \mu \mathrm{m}$. 
Achillea Linnaeus

Achillea millefolium $\mathrm{L}$.

(Figs. 13-15)

Pollen grains of medium size, suboblate, amb subtriangular, 3-colporate, longiaperturate colpi and narrow. Endoaperture lalongate, without central constriction (Fig. 14). Exine with well-delimited cavea, short spines (with about 4 columellae) much wider at the base than long (index 0.61), spines conical shaped. Around 11 spines in polar view.

Note: Herbaceous plant, perennial. Exotic, cultivated in almost the whole of Brazil (Lorenzi \& Matos 2002).

\section{Gnaphalium Linnaeus}

\section{Gnaphalium purpureum L.}

$$
\text { (Figs. 16-18) }
$$

Pollen grains of small size, prolate-spheroidal, amb subcircular. Aperture longiaperturate colpi and narrow, endoaperture lalongate, with central constriction (30\%) or without central constriction (70\%). Exine with welldelimited cavea, short spines (with about 3 columellae) much wider at the base then long (index 0.63). Around 12 spines in polar view.

Note: Herbaceous plant, annual. Exotic, found in shaded and not very dry soils (Lorenzi 2000).

Mutiseae Cass.

(Figs. 19-24)

Pollen grains of medium size; isopolar; radial symmetry; amb triangular or subtriangular (Fig. 19); oblate-spheroidal orprolate; 3-colporate; microechinate. Aperture longiaperturate colpi, and narrow, with indistinct tips, with or without central constriction (Figs. 23, 20). Endoaperture lalongate, without central constriction (Figs. 20, 23). Exine with two distinct layers (sexine and nexine) without cavea. Sexine bi-stratified, with sexine 3 (columellae), sexine 4 (tectum), sexine 1 (columellae) and sexine 2 (tectum with spicules) (on the tectum rests a new line of smaller columellae, also united by a tectum). Spicules sparsely distributed on the surface of the exine which makes it slightly waved (Fig. 23). The sexine is thicker than the nexine.

\section{Chaptalia graminifolia (Dusén ex Malme) Cabrera} (Figs. 19-21)

Pollen grains oblate-spheroidal, amb subtriangular, 3 -colporate, with a slight central constriction, endoaperture lalongate, without central constriction (Fig. 20). Exine marked thickening of the exine at the mesocolpium (mean $3.81 \mu \mathrm{m}$ ) in relation to the pole (mean $2.74 \mu \mathrm{m}$ ).

Note: Herbaceous plant, perennial. Native, occurs in dry and stony fields in the southern states of Brazil (Cabrera \& Klein 1973, Roque 2015).

\section{Chaptalia integerrima (Vell.) Burkart}

(Figs. 22-24)

Pollen grains prolate, amb triangular, 3-colporate, with a slight central constriction $(80 \%)$ or without central constriction (20\%), endoaperture lalongate, without central constriction (Fig. 23). Exine marked thickening of the exine at the mesoculpium (mean $4.19 \mu \mathrm{m}$ ) in relation to the pole (mean $2.62 \mu \mathrm{m}$ ).

Note: Herbaceous plant, perennial. Native, occurring mainly in lean or stony fields or in coastal forests (Cabrera \& Klein 1973, Roque 2015).

Senecioneae Cass.

(Fig. 25-30)

Pollen grains of medium size; isopolar; radial symmetry; amb subcircular (Fig. 25); prolate espheroidal; 3-colporate; echinate. Aperture longiaperturate colpi, with acute ends, no central constrictions (Figs. 26, 29). Endoaperture circular or lalongate, with acute ends, without central constriction (Figs. 26, 29). Exine with two distinct layers (sexine and nexine) indistinct cavea. Simplicolumellate exine with sexine 1 (columellae), sexine 2 (tectum) and sexine 3 (spines, sculpture elements). The structure of the spines is of columellar and tegillum type, meaning they have a perforation at the base. Spines slightly longer than wide at the base or as long as wide at the base, conical shaped, slightly dome shaped (swollen at the base), with acute and straight spine apex or with curved spine apex (Fig. 28). Sexine 2 times thicker than the nexine.

\section{Emilia Cass.}

Emilia sonchifolia (L.) DC.

(Figs. 25-27)

Pollen grains prolate-spheroidal, amb subcircular, 3 -colporate, long and narrow, and without central constriction, endoaperture circular (Fig. 26). Exine with indistinct cavea, spines columellate (with about 5 columellae), isolated, a little wider at the base than tall (index 0.98). About 15 spines in polar view.

Note: Herbaceous plant, annual. Native, found throughout Brazil (Borges \& Teles 2015, Lorenzi \& Matos 2002).

\section{Senecio L.}

Senecio brasiliensis (Spreng.) Less.

(Figs. 28-30)

Pollen grains prolate-spheroidal, amb subcircular, 3-colporate, broad colpi at the equator with acute ends, without central constriction, endoaperture lalongate, without central constriction (Fig. 29). Exine indistinct cavea, spines columellate (with about 4 columellae), isolated, spines much wider at the base than tall (index 0.64). About 14 spines in polar view.

Note: Herbaceous, sub-shrubby or shrubby plant, perennial. Native, found throughout Brazil (Lorenzi 2000, Teles 2015). 

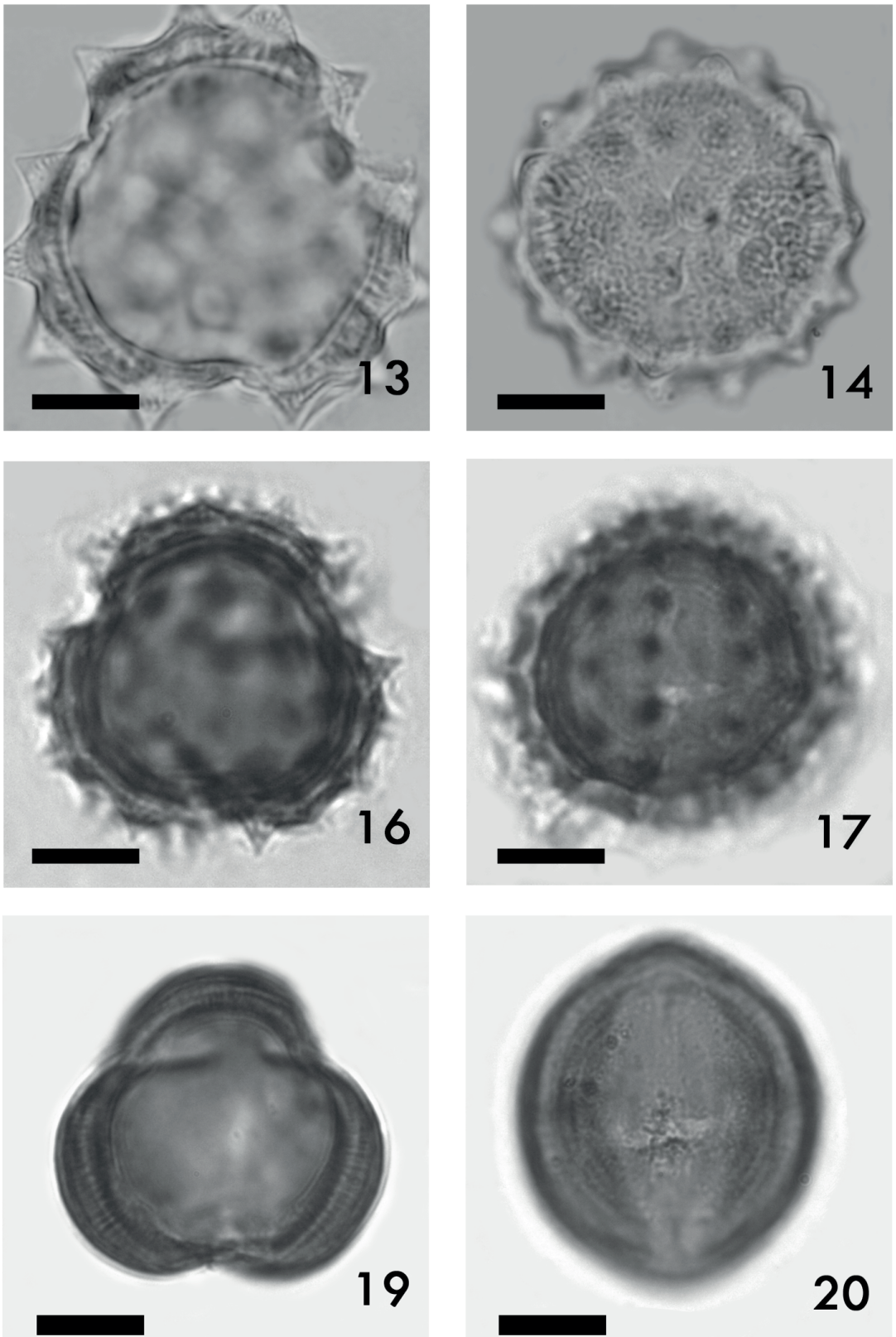
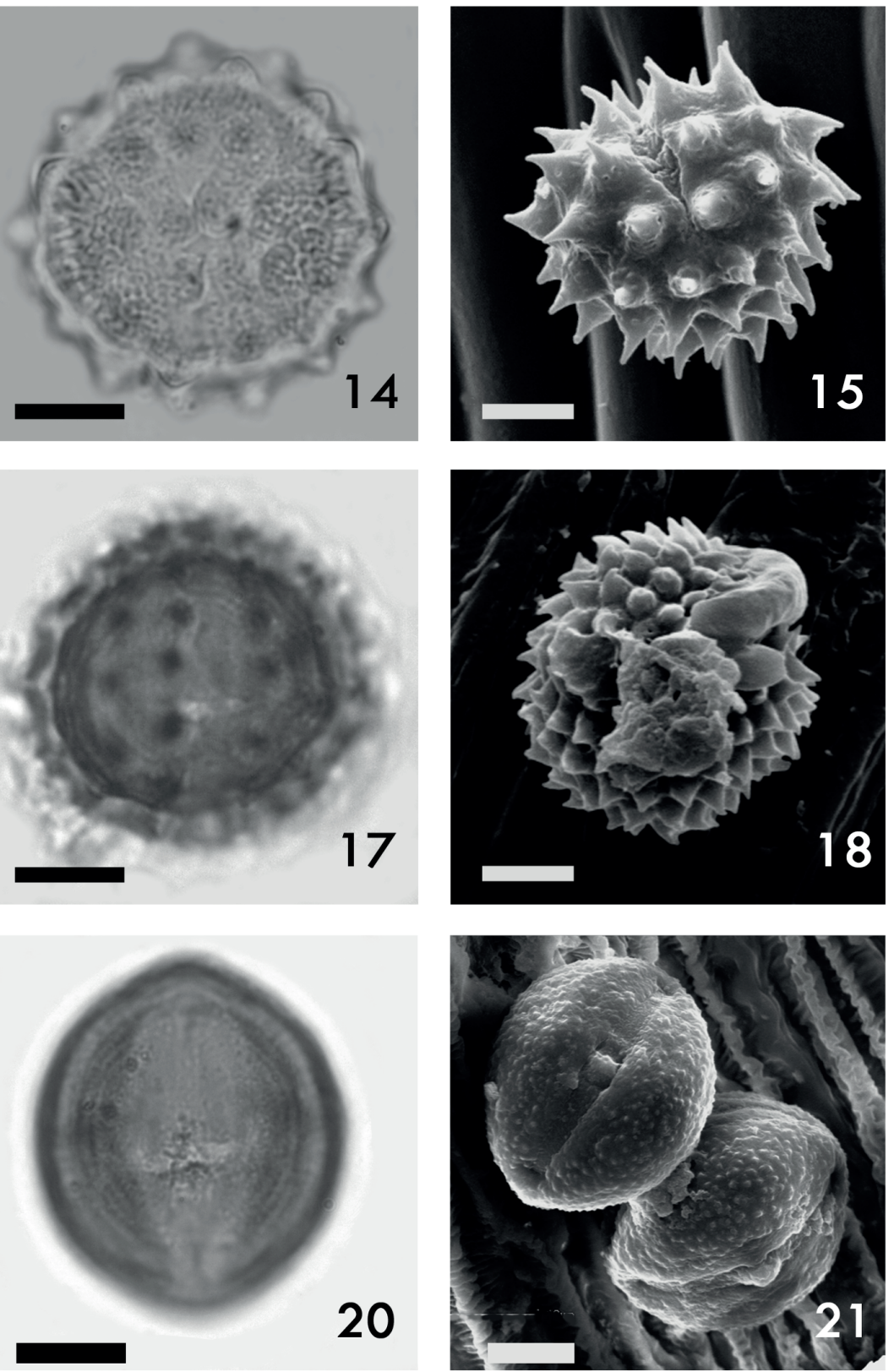

Figs. 13-21. Pollen grains of Asteraceae, tribes Inuleae and Mutiseae. 13-15. Achillea millefolium. 13. Polar view (MO); 14. Equatorial view (MO); 15. General aspect, ornamentation (MEV). 16-18. Gnaphalium purpureum. 16. Polar view (MO); 17. Equatorial view (MO); 18. General aspect (MEV). 19-21. Chaptalia graminifolia. 19. Polar view (MO); 20. Equatorial view (MO); 21. General aspect (MEV). Bars: Figs. 13, 14, 16, 17, 19, 20, $21=10 \mu \mathrm{m}$; Figs. 15, $18=5 \mu \mathrm{m}$.

\section{DISCUSSION}

In the Eupatorieae tribe, the pollen type called Eupatorium, created by Stix (1960), has the characteristics of small (in size) pollen grains, oblate-spheroidal and prolatespheroidal, lalongate endoapertures and the columellar structure of the spines of tegillum type, corroborating with the results in the analyzed taxa. Nair \& Lawrence (1985) analyzed the pollen morphology of 10 taxa from the Eupatorieae tribe, including Mikania micranta, which have very similar characteristics to this description, and verified that pollen grains of the Eupatorieae were similar to species of Astereae, with small pollen grains and echinate exine.

Chromolaena laevigata (Lam.) R. M. King \& H. Rob. (Eupatorium laevigatum Lam.) was palynologically studied by Cancelli et al. (2010), differing from our description in relation to pollen grain dimensions, described by the author as medium in size. On the other hand, Vittetia orbicula, had not yet been palynologically studied, which has oblate-spheroidal pollen grains, small and with lalongate endoaperture.

Two species of the genus Chaptalia were analyzed in which C. integerrima was previously studied by Cancelli et al. (2010) who described the pollen grain as prolate-spheroidal, and Pastana (1988), who described it 

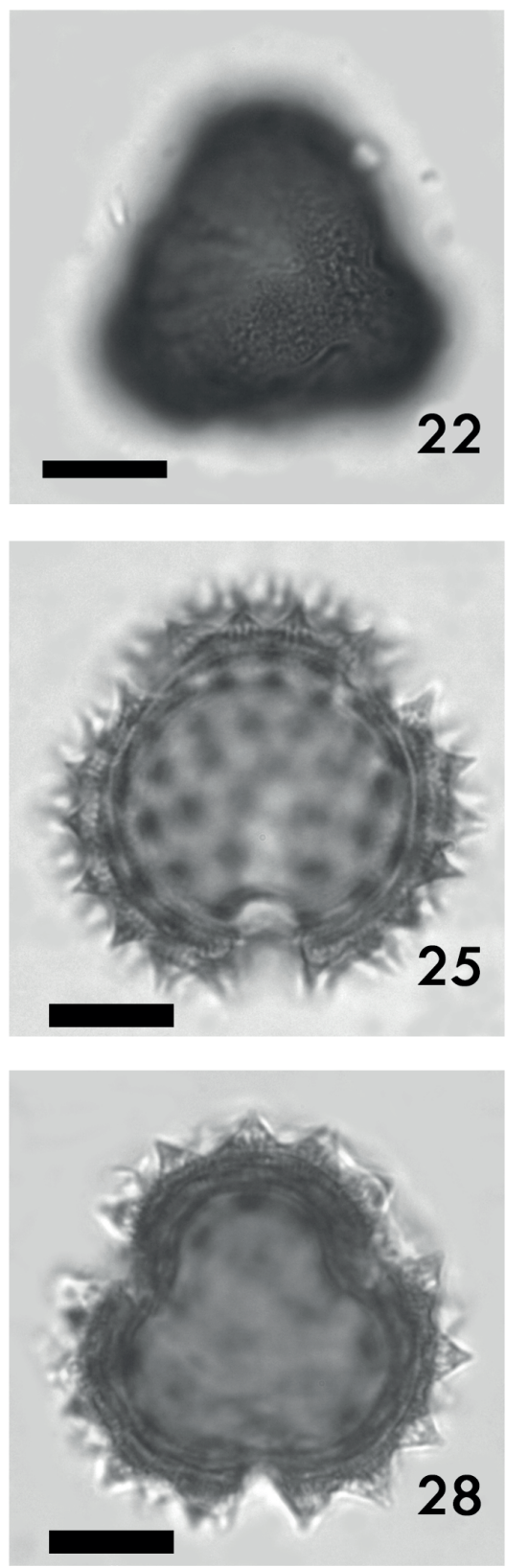
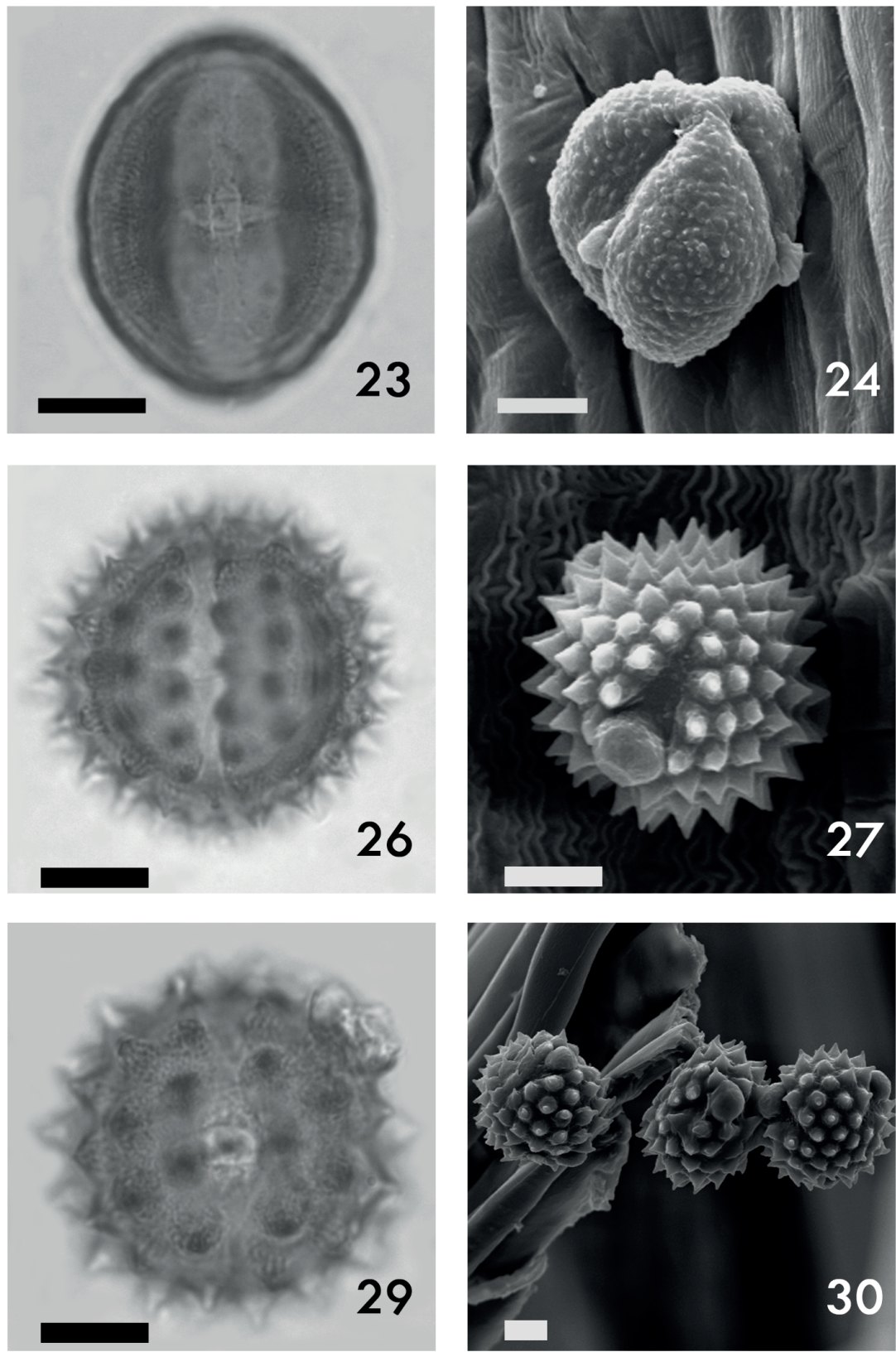

Figs. 22-30. Pollen grains of Asteraceae, tribes Mutiseae and Senecianeae. 22-24. Chaptalia integerrima. 22. Polar view (MO); 23. Equatorial view (MO); 24. General aspect (MEV). 25-27. Emilia sonchifolia. 25. Polar view (MO); 26. Equatorial view (MO); 27. General aspect (MEV). 28-30.

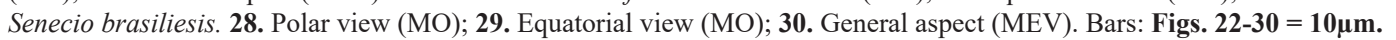

as suboblate. The other characteristics presented by the aforementioned authors were similar to our descriptions. The other characteristics were similar to the observations in this study. Melhem et al. (2003) also studied C. integerrima describing the pollen grains as prolate-spheroidal, with a lalongate endoaperture, having marked thickening at the mesocolpium. However, C. graminifolia had not yet been palynologically studied. In this study, it presents pollen grain oblate-spheroidal, amb triangular, colporate, with slight median constriction and lalongate endoaperture.

The species of the Senecioneae tribe, Emilia sonchifolia and Senecio brasiliensis, although not belonging to the same genus, were similar in size, shape and amb (medium, prolate-spheroidal, and sub circular amb). Emilia sonchifolia was described by Adedeji (2005) with tricolporate pollen grains, and it is the only species of the described genus in Nigeria with 4-colporate medium (in size) pollen grains. However, here it was possible to observe only tricolporate pollen grains. Cancelli et al. (2010) described S. brasiliensis presenting small in size pollen grains and prolate-spheroidal, coinciding in part with the observations of this study.

Achillea millefolium and Matricaria chamomilla are among the many medicinal plants included in the Asteraceae family (Souza \& Lorenzi 2012). Galvão et al. (2009) described Matricaria recutita, basionym of Matricaria 
chamomilla L., popularly known as "Camomile", with medium in size pollen grains, larger than observed in the present study. Regarding the descriptions made by those authors, the pollen grains were described as isopolar, oblatespheroidal, of subtriangular amb, 3-colporate and with an echinate exine, differing only in shape, described in this study as prolate-spheroidal.

Achillea millefolium pollen grains were studied by Meo $\&$ Khan (2003) in a study where two species of the Achillea genus were described. The analyzed specimen here shows tricolporate pollen grains medium in size, corroborating with the results described by Meo \& Khan (2003).

Breitwieser \& Sampson (1997) described the pollen grain in Gnaphalium with various types of columellae. In relation to Gnaphalium, some descriptions made by Perveen (1999) corroborate with the ones presented here for Gnaphalium purpureum, such as the small size, differing in shape, which was described by the authors as oblatespheroidal to sub-prolate. The morphological diagnosis obtained from small (in size) pollen grains, exine with caveae, with short, sharp and few spines groups the species of the Eupatorieae tribe (Chromolaena laevigata (Lam.) R. M. King \& H. Rob., Vittetia orbiculata (DC.) R. M. King \& H. Rob. and Mikania micrantha Kunth) with Gnaphalium purpureum L. of the tribe Inuleae, and showed its correspondence to the Eupatorium pollen type described by Stix (1960), as well as the pollen type Compositae-H (Helianthus) of Zander (1935), or also of the pollen type EU (Eupatorium) of Barth (1989).

The two taxa analyzed from the Mutiseae, Chaptalia integerrima (Vell.) Burkart and Chaptalia graminifolia (Dusén ex Malme) Cabrera, were distinguished from the other species due to having medium size pollen grains and not having spines, but sparsely distributed spicules on the exine surface, making it slightly wavy, with two-stratum sexine. The pollen morphology of these species is related to the pollen type Centaurea described by Stix (1960).

On the other hand, the medium sized pollen grains with large, tall and numerous spines of Emilia sonchifolia (L.) DC. and Senecio brasiliensis (Spreng.) Less. classified them in the pollen type Senecio of Stix (1960), or Compositae-H pollen type (Helianthus) of Zander (1935), or also of the Compositae S (Senecio) pollen type by Barth (1989).

Two species of different tribes (Achillea millefolium L. - Inuleae and Matricaria chamomilla L.-Anthemideae) were grouped in the pollen type Anthemis of Stix (1960) by presenting long columellae configuring the thickest sexine 1 among the analyzed species.

The five tribes analyzed were considered eurypalynous, whose morphological detail allowed the subdivision of species in four groups related to pollen types Anthemis, Eupatorium, Centaurea and Senecio previously defined in the literature. However, the morphological similarities in pollen grains of the species of the Mutiseae and Senecioneae tribes as to the size of the openings, sexine layers and appearance of the spine or spicules, considered them as stenopalynous, i.e., with a great morphopalynological similarity that do not taxonomically separate these species. The same occurred with Gnaphalium purpureum (Inuleae), with all species belonging to the Eupatorieae tribe. They were also grouped to the Achillea millefolium of the Inuleae tribe and Matricaria chamomilla of the Anthemideae tribe. The groups formed by these species may be used in applied research that uses Palynology as the reconstruction of paleoenvironments and paleovegetation.

\section{ACKNOWLEDGEMENTS}

To the Laboratories of Botany, Palynology, and Scanning Electron Microscopy of the State University of Ponta Grossa (UEPG), Paraná. We thank the Institute of Botany, Environmental Department of São Paulo State, Brazil, for allowing us to use the facilities and equipment of the Center for Research in Palynology. To Dr. José Ivanildo de Souza from the Institute of Botany for lending a microscope LEICA DM 2500.To the Coordination of Improvement of Personal Higher Education (CAPES) to the first author. We thank the National Council of Scientific and Technological Development (CNPq) for the fellowship of "Produtividade em Pesquisa" to the last author (Process number 302766/2016-2).

\section{REFERENCES}

Adedeji, O. 2005. Pollen morphology of the three species of the genus Emilia CASS. (Asteraceae) from Nigeria, Thaiszia. Journal of Botany 15:1-9.

Angiosperm Phylogeny Group. 2009. An update of the phylogeny group classification for the orders and families of flowering plants: APG III. Botanical Journal of the Linnean Society 161:105-21.

Barth, O.M. 1989. O pólen no mel brasileiro. Gráfica Luxor, Rio de Janeiro. $151 \mathrm{p}$.

Barth, O.M, Luz, C.F.P. \& Gomes-Klein, V.L. 2005. Pollen morphology of Brazilian species of Cayaponia Silva Manso (Cucurbitaceae, Cucurbiteae). Grana 44:129-136.

Borges, R.A.X. \& Teles, A.M. 2015. Emilia in Lista de Espécies da Flora do Brasil. Jardim Botânico do Rio de Janeiro. Disponível em: http:// floradobrasil.jbrj.gov.br/jabot/floradobrasil/FB16105. Acessado em 19.04.2017.

Breitwieser, I. \& Sampson, F.B. 1997. Pollen characteristics of New Zealand Gnaphalieae (Compositae) and their taxonomic significance II. Grana. 36 (2):80-95.

Cabrera, L.A. \& R.M. Klein. 1973. Flora Ilustrada Catarinense. Plantas Compostas Tribo: Mutiseae. Editora Raulino Reitz. Itajaí. 124p.

Cabrera, L.A. \& Klein, R.M. 1989. Plantas Compostas -Tribo: Eupatorieae. Flora Ilustrada Catarinense, p. 317-319.

Cancelli, R.R. 2008. Palinologia de Asteraceae: morfologia polínica e suas implicações nos registros do Quaternário do Rio Grande do Sul. Dissertação 173 f., Universidade Federal do Rio Grande do Sul, Porto Alegre.

Cancelli, R.R., Evaldt, A.C.P., Bauermann, S.G., Souza,P.A., Bordignon, S.A.L. \& Matzenbacher, N.I. 2010. Catálogo palinológico de táxons da família Asteraceae Martinov, no Rio Grande do Sul, Brasil. Iheringia. Série Botânica 65:201-280.

Cancelli, R.R., Macedo, R.B., Guerreiro, C.T. \& Bauermann, S.G. 2005. Diversidade Polínica em Asteraceae Martinov da Fazenda São Maximiniano, Guaíba, RS. Pesquisas. Série Botânica 56:209-228.

Coutinho, A.P. \& Dinis, A.M. 2007. A contribution to the ultrastructural knowledge of the pollen exine in subtribe Inulinae (Inuleae, Asteraceae). Plant Systematics and Evolution 269:159-170.

Erdtman, G. 1952. Pollen morphology and plant taxonomy-Angiosperms: an introduction to palynology. Alquimist \& Wikseus, Stockholm. 553 p. 
Ferreira, S.C. 2015. Vittetia in Lista de Espécies da Flora do Brasil. Jardim Botânico do Rio de Janeiro. Disponível em: http:// floradobrasil.jbrj.gov.br/jabot/floradobrasil/FB111979. Acessado em 19.04.2017.

Galvão, M.N., Pereira, A.C.M., Gonçalves-Esteves, V. \& Esteves, R.L. 2009. Palinologia de espécies de Asteraceae de utilidade medicinal para a comunidade da Vila Dois Rios, Ilha Grande, Angra dos Reis, RJ, Brasil. Acta Botânica Brasilica 23:247-258.

Lorenzi, H. 2000. Plantas daninhas do Brasil: terrestres, aquáticas, parasitas e tóxicas. Instituto Plantarum, Nova Odessa, São Paulo. $608 \mathrm{p}$.

Lorenzi, H. E. \& Matos, F.J. De A. 2002. Plantas medicinais no Brasil. Nativas e exóticas. Instituto Plantarum, Nova Odessa, São Paulo. 512 p.

Melhem, T.S., Cruz-Barros, M.A.V., Corrêa, A.M.S., Makino-Watanabe, H., Silvestre-Capelato, M.S. \& Esteves, V.L.G. 2003. Variabilidade polínica em plantas de Campos do Jordão (São Paulo, Brasil). Boletim do Instituto de Botânica 16:16-104.

Mendonça, C.B. \& Gonçalves-Esteves, V. 2000. Morfologia polínica de algumas espécies da tribo Vernonieae (Compositae Giseke) da Restinga de Carapebus, Rio de Janeiro. Hoehnea 27:131-142.

Meo, A.A. \& Khan, M. A. 2003. Pollen morphology of Achillea (Compositae-Anthemideae) species from Pakistan. Pakistan Journal of Weed Science Research 9(3-4):253-258.

Mondin, C.A. 2006. Riqueza genérica e dados biogeográficos das Asteráceas brasileiras. In Congresso Nacional de Botânica. Sociedade Brasileira de Botânica, Porto Alegre, p. 209-211.

Nair, P.K.K. \& Lawrence, R. 1985. Advances in pollen spore. v. 14 Scholar Publishing House, New Delhi.

Nakajima, J.N., Loeuille, B.,Heiden, G.,Dematteis, M.,Hattori, E.K.O.,Magenta, M.A.G.,Ritter, M.R.,Mondin, C.A.,Roque, N.,Ferreira, S.C.,Borges, R.A.X.,Soares, P.N.,Almeida, G.,Schneider, A.,Sancho, G.,Saavedra, M.M.,Liro, R.M.,Pereira, A.C.M.,Moraes, M.D.,Silva, G.A.R.,Medeiros, J.D.,Lorencini, T.S.,Teles, A.M.,Monge, M.,Siniscalchi, C.M.,Souza-Buturi, F.O.,Bringel Jr., J.B. A.,Carneiro, C.R.,Pasini, E.,Oliveira, C.T. 2015. Asteraceae in Lista de Espécies da Flora do Brasil. Jardim Botânico do Rio de Janeiro. Disponível em: http://floradobrasil.jbrj.gov.br/reflora/ floradobrasil/FB80681. Acessado em 18.04.2017.
Oliveira, C.T. 2015. Chromolaena in Lista de Espécies da Flora do Brasil. Jardim Botânico do Rio de Janeiro. Disponível em: http:// floradobrasil.jbrj.gov.br/jabot/floradobrasil/FB16058. Acessado em 19.04.2017.

Pastana, G.I.I. 1988. Contribuição preliminar aos tipos polínicos da Tribo Mutisieae (Compositae). Acta Botanica Brasilica 2 (1):55-66.

Perveen, A.1999. Contributions to the Pollen morphology of the family Compositae. Turkish Journal Of Biology 23:523-535.

Punt, W., Blackmore, S., Nilson, S. \& Le Thomas, A. 2007. Glossary of pollen and spore terminology. Review of Paleobotany and Palynology $143: 1-81$.

Punt, W. \& Hoen, P.P. 2009. The Northwest European Pollen Flora, 70: Asteraceae -Asteroideae. Review of Palaeobotany and Palynology 157:22-183.

Ritter, M.R., Liro, R.M.,Roque, N.,Nakajima, J.N.,Souza-Buturi, F.O.,Oliveira, C.T. 2015. Mikania in Lista de Espécies da Flora do Brasil. Jardim Botânico do Rio de Janeiro. Disponivel em: http:// floradobrasil.jbrj.gov.br/jabot/floradobrasil/FB5456. Acessado em 19.04.2017.

Roque, N., Monge, M. 2015. Chaptalia in Lista de Espécies da Flora do Brasil. Jardim Botânico do Rio de Janeiro. Disponível em: http:// floradobrasil.jbrj.gov.br/jabot/floradobrasil/FB104568. Acessado em 19.04.2017.

Salgado-Labouriau, M.L. 1973. Contribuição à Palinologia dos Cerrados. Academia Brasileira de Ciências. Rio de Janeiro. 291 p.

Souza, V.C. \& Lorenzi, H. 2012. Botânica Sistemática: Guia ilustrado para identificação das famílias de Fanerógamas nativas e exóticas no Brasil, baseado em APG III. Instituto Plantarum, Nova Odessa. 640 p.

Stanski, C., Luz, C.F.P., Nogueira, N. \&Nogueira, M.K.F.S. 2013. Palynology of species in the Astereae and Heliantheae tribes occurring in the region of Campos Gerais, Paraná State, Brazil. Iheringia, Série Botânica 68:203-215.

Stix, E. 1960.Pollen morphologisch e Untersuchun genan Compositen. Grana Palynology, 2:41-126.

Teles, A.M. 2015. Senecio in Lista de Espécies da Flora do Brasil. Jardim Botânico do Rio de Janeiro. Disponível em: http://floradobrasil. jbrj.gov.br/jabot/floradobrasil/FB27354. Acessado em 19.04.2017.

Zander, E. 1935. Beitraegezur Herkunftsbestimmungbei Honig. I. Verlag der ReichsfachgruppeImker E.V, Berlin. 